ENCYCLOPEDDIE Encyclopédie berbère

BERBERE

$34 \mid 2012$

34| Nemencha - Nybgenii

\title{
N'Kheïla (Maroc)
}

\section{Georges Souville}

\section{OpenEdition}

Journals

Édition électronique

URL : https://journals.openedition.org/encyclopedieberbere/2745

DOI : $10.4000 /$ encyclopedieberbere. 2745

ISSN : 2262-7197

\section{Éditeur}

Peeters Publishers

\section{Édition imprimée}

Date de publication : 5 octobre 2012

Pagination : 5559-5560

ISBN : 978-90-429-2718-6

ISSN : 1015-7344

\section{Référence électronique}

Georges Souville, "N'Kheilla (Maroc) », Encyclopédie berbère [En ligne], 34 | 2012, document N60, mis en ligne le 15 décembre 2020, consulté le 17 février 2022. URL : http://journals.openedition.org/ encyclopedieberbere/2745; DOI : https://doi.org/10.4000/encyclopedieberbere.2745

Ce document a été généré automatiquement le 17 février 2022.

(c) Tous droits réservés 


\section{N'Kheilla (Maroc)}

\section{Georges Souville}

1 Deux stèles découvertes au sud-ouest du camp militaire de N'Kheïla (Maroc), près d'un seyyed en creusant une tranchée, présentent des caractères communs. L'une montre dans la partie centrale le corps d'un personnage nu, les bras collés au corps ; il n'est pas possible de distinguer le sexe. Au sommet et sur les côtés, des demi-cercles concentriques sont creusés, prolongés par des rangs d'ondes se rabattant sur la tranche, et sont séparés de la partie centrale par des lignes sinueuses. Dans l'état actuel, le bas ayant disparu, elle mesure $0,52 \mathrm{~m}$ de large, $0,84 \mathrm{~m}$ de hauteur et $0,11 \mathrm{~m}$ d'épaisseur. L'autre stèle est très altérée et a perdu la partie supérieure. Là aussi existent des séries de lignes concentriques encadrant également un personnage nu ; la partie supérieure disparue devait avoir la représentation de la tête.

2 Ces deux stèles appartiennent à la civilisation du Bronze atlantique et ne peuvent être rattachées, comme l'avaient cru J. Bourrilly et E. Laoust, aux pierres funéraires d'Agadir et de Mogador post-romaines. 


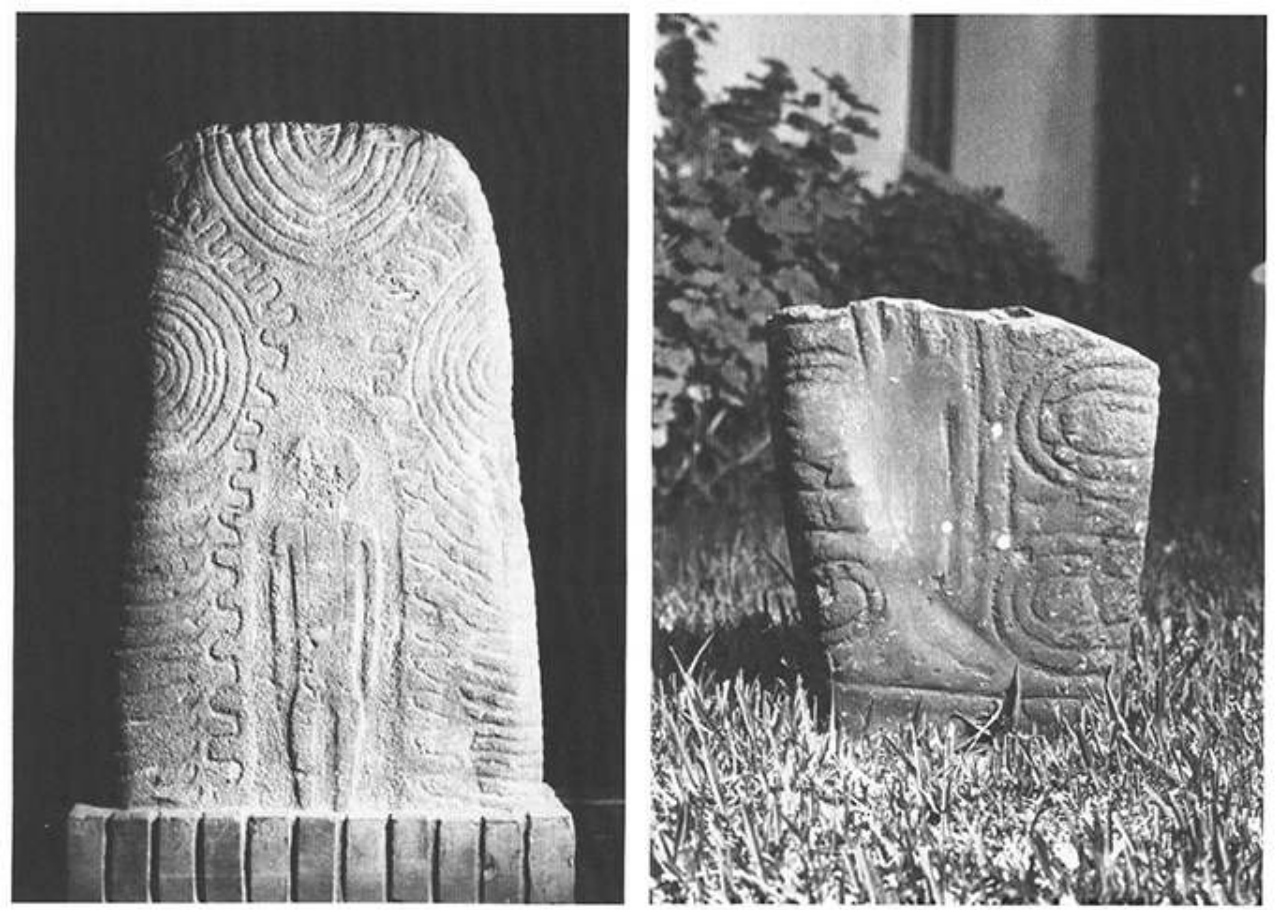

Fig. 1 \& 2. LES STÈLES DE N'KHEÏLA

Cliché G. Souville.

BIBLIOGRAPHIE

BASSET H., 1923 - « Deux pétroglyphes du Maroc occidental (région des Zaïer) », Hespéris, t. 3, 2 pl. h.t.

SOUVILLE G., 1971 - « Stèles gravées du Maroc occidental », Boll. Centro camuno Studi preist., t. 7, p. 77-85, fig. 26-33.

SOUVILLE G., 1973 - Atlas préhistorique du Maroc, 1. Le Maroc atlantique, Paris, CNRS (Coll. Etudes d'Antiquités africaines), p. 333-338, fig. 146-149.

\section{INDEX}

Mots-clés : Art rupestre, Maroc, Protohistoire 